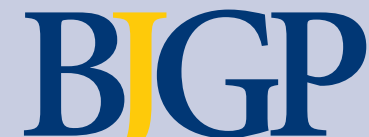

EDITOR

Roger Jones, DM, FRCP, FRCGP, FMedSci London

DEPUTY EDITOR

Alec Logan, FRCGP

Motherwell

JOURNAL MANAGER

Catharine Hull

SENIOR ASSISTANT EDITOR

Erika Niesner

ASSISTANT EDITOR

Moira Davies-Cinar

EDITORIAL ASSISTANT

Tania Marszalek

ADVERTISING EXECUTIVE

Brenda Laurent

EDITORIAL BOARD

Richard Baker, MD, FRCGP

Leicester

Stephen Barclay, MD, FRCGP, DRCOG

Cambridge

Chris Butler, MD, MRCGP

Cardiff

Kath Checkland, PhD, MRCGP

Manchester

Mark Gabbay, MD, FRCGP

Liverpool

Murray Lough, MD, FRCGP

Glasgow

David Mant, MD, FRCGP, FMedSci

Oxford

Nigel Mathers, MD, FRCGP, DCH

Sheffield

Tim Peters, MSc, PhD, CStat, FFPH

Bristol

Chris Salisbury, MD, FRCGP

Bristol

John Sandars, MSc, MD, FRCGP, MRCP

Leeds

Mark Shapley, FRCGP, DCH, DRCOG

Newcastle-under-Lyme

Niroshan Siriwardena, MMedSci, PhD, FRCGP

Lincoln

Theo Verheij, MD, PhD, MRCGP

Utrecht, The Netherlands

Sue Wilson, BA, PhD, PGA

Birmingham

2009 impact factor: 2.442

EDITORIAL OFFICE

1 Bow Churchyard, London, EC4M 9DQ

(Tel: 0203188 7400, Fax: 0203188 7401).

E-mail: journal@rcgp.org.uk

http://www.rcgp.org.uk/bjgp

PUBLISHED BY

The Royal College of General Practitioners,

1 Bow Churchyard, London, EC4M 9DQ.

Registered charity number 223106. The BJGP is

published by the RCGP, but has complete

editorial independence. Opinions expressed in the

BJGP should not be taken to represent the policy

of the RCGP unless this is specifically stated.

No endorsement of any advertisement is implied or intended by the RCGP.

PRINTED IN GREAT BRITAIN BY

hpmgroup, Prime House, Park 2000, Heighington

Lane Business Park,

Newton Aycliffe, Co. Durham DL5 6AR.

Printed on $100 \%$ recycled paper

\title{
December Focus
}

\section{LOOKING BACK, LOOKING FORWARD}

As well as containing an excellent bunch of research papers, this month's BJGP celebrates two important milestones in its history - the 50th anniversary of the first publication of the Journal of the College of General Practitioners, without the appended College Research Newsletter, in 1960 and the establishment of the Journal's International Advisory Board during 2010. But first the papers.

The overall theme is therapeutic interventions. Stanton and colleagues provide a valuable overview of the evidence guiding clinical decision making in patients with respiratory tract symptoms and infections, and offer a series of practical suggestions aimed at improving their management. These include the use of structured scoring systems to rule in or out bacterial infections, shared decision making, the provision of patient information, and the use of deferred prescribing in certain defined circumstances (page 916). In their study from Oslo, Hoye and co-workers discovered that deferred prescribing was not always endorsed by GPs, and emphasise the need for careful negotiation and the provision of information to patients when issuing waitand-see prescriptions (page 907). Non-drug approaches to the management of hypertension and gastro-oesophageal reflux disease are explored in a systematic review from Ireland (page 924) and an evaluation of a group intervention from London (page 891), both suggesting that patients have an important role to play in the effective management of both conditions. Inappropriate use of antibiotics is likely to have contributed to the high rate of nasal carriage of resistant strains of Staphylococcus aureus by GPs in the Netherlands (page 902), while the telling case history by Bolton et al illustrates the need to look beyond the acute treatment of gout in younger patients, and to consider the likelihood of increased cardiovascular risk lying behind the inflamed joint (page 913).

The Journal's golden anniversary is marked in the Back Pages by a series of short pieces by all but one of its editors, tracing the development of one of the world's oldest and most influential primary care publications, growing out of a cottage industry fuelled by goodwill and commitment to the highly professional publishing operation that now runs in the College's Journal office. Despite that, however, the problems facing successive editors had much in common, such as the balance between research and nonresearch content, the Journal's responsibility to the academic publishing community versus its relevance to the wider RCGP membership, the need to protect editorial independence, and the importance of competing in the wider world of academic publishing where editors live and die by their Impact Factors. Additional preoccupations for the new decade include working out how best to use the emerging publishing and communications technologies, creating an interactive electronic web presence for the BJGP, launching a newly designed Journal with short paper summaries of research, backed up by continuous online publication of full papers ahead of print, making Journal content readily available to countries outside the Organisation for Economic Cooperation and Development and, increasingly, keeping a close watch on the financial bottom line.

We also want to see the authorship, readership, and influence of the BJGP extend around the globe, and are delighted to announce the membership of the BJGP's first International Advisory Board, described more fully in a short editorial (page 881). We are also proud to lead this issue of the Journal with Jan de Maeseneer's call to action for primary care to engage with the promotion of global health and to work towards the attainment of the Millennium Development Goals (page 875). When I heard Jan lecture about this earlier in the year I felt that I had missed out on making the sort of contribution to global health that might be expected of academic and service general practice in this and other developed countries. Whether through advocacy for primary care in political circles, the support of researchers and teachers in other countries, direct action to help build primary care in the third world, or using publishing technologies to bring clinical evidence and practical advice to isolated and underresourced communities at low cost something which the BJGP already does through the World Health Organization's HINARI agreement and which I hope we can extend further in the future.

\section{Roger Jones \\ Editor}

DOI: 10.3399/bjgp10X539470

(c) British Journal of General Practice 2010; 60: 873-952. 